\title{
MONKEY BITES AND INJURIES IN THE ZAGREB ANTIRABIES CLINIC IN 2014
}

\author{
Radovan Vodopija ${ }^{1}$, Daniela Vojvodić ${ }^{1}, \mathrm{Kruno}$ Sokol ${ }^{1}$, Aleksandar Racz ${ }^{2}$, \\ Željka Gregurić Beljak ${ }^{1}$, Nikolina Baranj ${ }^{1}$, Jasna Mahović ${ }^{1}$ and Branko Ulaga ${ }^{1}$ \\ ${ }^{1}$ Dr. Andrija Štampar Teaching Institute of Public Health, Zagreb, Croatia; \\ ${ }^{2}$ University of Applied Health Sciences, Zagreb, Croatia
}

\begin{abstract}
SUMMARY - Travelling around the world and visiting distant places and countries (especially national parks, parks of nature, natural resorts, etc.) sometimes may result in animal bites and injuries from the species which are not usually represented as the source of human rabies cases, such as monkeys. In the last ten to fifteen years, monkey bites and injuries present an unpleasant experience and cause a lot of problems for travelers and tourists when travelling to India, Thailand, Indonesia or Bali because they have to seek a medical facility for wound treatment, tetanus prophylaxis, antimicrobial therapy and rabies postexposure prophylaxis (PEP).In 2014, 706 persons were registered at the Zagreb Antirabies Clinic as having sustained bites by various animals, ten of them reported to have been bitten or injured by monkeys. Nine of them sustained injuries during their travel to India, Thailand, Indonesia and Bali. All injuries occurred when they wanted to pet or tried to feed monkeys, or refused to give them food. Most of the monkeys were macaques, capuchins, or of unknown type. Only one monkey bite recorded in the city of Zagreb occurred in the Zagreb ZOO while a professional animal handler was feeding a capuchin monkey in the cage. He did not receive rabies PEP, but instead, the capuchin monkey was put under veterinary supervision. All other patients started with PEP in the countries where the injuries occurred and continued/completed it at the Zagreb Antirabies Clinic. They received antirabies vaccine only (PVRV, RABIPUR) upon 5-dose regimen (Essen scheme) and 2-1-1 (Zagreb scheme) regimen. None of them contracted rabies. After many years, monkeys were the animal species immediately following dogs and cats in the official report of the Zagreb Antirabies Clinic, which was quite surprising. Usually, monkey bites and injuries do not present a serious problem in daily routine because they occur sporadically.
\end{abstract}

Key words: Travel; Haplorbini; Rabies; Bites and injuries; Croatia

\section{Introduction}

There are several key factors in determining the risks to which a traveler may be exposed, including mode of transport, destination, duration, season and purpose of travel, standards of accommodation, food hygiene and sanitation, and traveler's behavior and underlying health ${ }^{1}$. During economic crisis, many travel agencies lower prices of their travel arrangements to

Correspondence to: Radovan Vodopija, $M D, P h D$, Dr. Andrija Štampar Teaching Institute of Public Health, Mirogojska 16, HR-10000 Zagreb, Croatia

E-mail: radovan.vodopija@stampar.hr

Received November 15, 2017, accepted December 5, 2017 attract more people to visit various destinations. Many of these arrangements are much cheaper.

In 2014, there were ten monkey bites and injuries registered at the Zagreb Antirabies Clinic. Nine of them were imported cases from India, Thailand, Indonesia and Bali, whereas only one event occurred at the Zagreb ZOO. Details of these cases are presented below.

\section{Results}

\section{Case 1}

A 28-year-old man, a professional animal handler, was bitten by a capuchin monkey at the Zagreb ZOO 
while microchipping the animal. The monkey was fed prior to the procedure. The patient was prescribed tetanus shot and antimicrobial therapy by his general practitioner. He did not receive postexposure rabies prophylaxis (PEP). The monkey was put under veterinary supervision and remained healthy during and after the monitoring period.

\section{Case 2}

A 65-year-old retired woman presented to the $\mathrm{Za}-$ greb Antirabies Clinic for continuing the rabies treatment according to the 5-dose regimen by Essen scheme, after being bitten by a monkey in the city of Agra while visiting Taj Mahal. The bite and injury occurred very quickly, so that she was unable to prevent it. While the rest of the group left the bus to take photos of Taj Mahal and monkeys, she stayed close to the bus. At the time of injury, she was eating potato chips; the monkey most probably wanted to get the food. She was bitten to her right underarm presumably by a macaque or capuchin monkey; the animal was medium size, not an apelike baboon, chimpanzee or gorilla (primates). The patient received her first dose of purified vero rabies vaccine (PVRV; Verorab), a tetanus shot and antibiotics in a local hospital. Human rabies immunoglobulin (HRIG) was not administered. PEP was continued and completed at the Zagreb Antirabies Clinic, with purified chick embryo cell vaccine (PCEC; Rabipur) rabies vaccine because PVRV was not available.

\section{Case 3}

A 33-year-old man, an electrician, was bitten by a monkey during his trip to India. The first aid, wound treatment, tetanus shot, and antibiotic therapy were administered in a local hospital. The patient was bitten to his lower limbs by, as he presumed, a macaque or capuchin monkey. Rabies treatment was commenced with antirabies vaccine only (PVRV) and HRIG was not administered. The patient received two shots of rabies vaccine on days 0 and 3 , and then returned to $\mathrm{Za}^{-}$ greb, where he finished PEP at the Zagreb Antirabies Clinic with PCEC (Rabipur) rabies vaccine because PVRV was not available.

\section{Case 4}

A 32-year-old woman, a marketing specialist, was bitten to her left fist in Thailand while trying to pet the monkey. She thought it was a macaque or capuchin monkey that injured her. Wound treatment, tetanus shot and antibiotics were provided at a local hospital. $\mathrm{PEP}$ with two doses of rabies vaccine (PVRV) on days 0 and 3 was started in Thailand. HRIG was not administered. After returning to Zagreb, PEP was continued and finished at the Zagreb Antirabies Clinic, with PCEC (Rabipur) rabies vaccine because PVRV was not available.

\section{Case 5}

A 35-year-old woman, a marketing advisor, was bitten in Thailand while trying to pet a monkey in the nature park. She sustained bite to her right fist, supposedly from a macaque or capuchin monkey. Wound treatment, tetanus shot and antibiotics were administered at a local hospital, where she also started PEP according to the 5-dose regimen. She received two doses of rabies vaccine (PVRV). HRIG was not administered. When she returned to Zagreb, PEP was continued and finished at the Zagreb Antirabies Clinic, with PCEC (Rabipur) rabies vaccine because PVRV was not available.

\section{Case 6}

A 20-year-old female student was bitten in Thailand while trying to pet the monkey in the nature park. She sustained bite to her left arm by, as she presumed, a macaque or capuchin monkey. Wound treatment, tetanus shot and antibiotics were provided at a local hospital, and she started PEP according to the 5-dose Essen regimen. She received four doses of rabies vaccine (PVRV). HRIG was not administered. PEP was completed at the Zagreb Antirabies Clinic, with PCEC (Rabipur) rabies vaccine because PVRV was not available.

\section{Case 7}

A 14-year-old girl, a pupil, was bitten in Bali while trying to pet a macaque or capuchin monkey. She sustained bite to her left upper arm. Wound treatment and wound suturing was performed at a local hospital, where she also received a tetanus shot. PEP was started in Bali with three doses of rabies vaccine (PVRV, Verorab) on days 0, 3 and 7. HRIG was not administered. After coming back to Zagreb, PEP was continued and completed at the Zagreb Antirabies Clinic upon 5-dose 
regimen (Essen scheme) with PCEC (Rabipur) rabies vaccine because PVRV was not available.

\section{Case 8}

A 35-year-old woman, an economist, was bitten in Bali while trying to pet a macaque or capuchin monkey. The patient sustained multiple bite injuries. Wound treatment was performed at a local hospital, where she also received a tetanus shot. PEP was started in Bali according to the Zagreb scheme. The patient received two doses of rabies vaccine (PVRV, Verorab) on day 0 i.m. in both deltoid muscles, and HRIG. PEP was continued and finished at the Zagreb Antirabies Clinic, with PCEC (Rabipur) rabies vaccine because PVRV was not available.

\section{Case 9}

A 34-year-old woman, an architect, was bitten in Bali while trying to feed a macaque or capuchin monkey. She was bitten to her right fist and fingers. Wound treatment was provided at a local hospital, where she also received a tetanus shot. PEP was started in Bali according to the Zagreb scheme. The patient received two doses of rabies vaccine (PVRV, Verorab) on day 0 i.m. in both deltoid muscles. HRIG was not administered. After she returned to Zagreb, PEP was continued and finished at the Zagreb Antirabies Clinic, with PCEC (Rabipur) rabies vaccine because PVRV was not available.

\section{Case 10}

A 29-year-old male, an IT engineer, was bitten in Indonesia while trying to feed a macaque or capuchin monkey. He sustained bite to his right fist and fingers. Wound treatment and tetanus shot were administered at a local hospital. PEP was started in Indonesia according to the Zagreb scheme with two doses of rabies vaccine (PVRV, Verorab) on day 0 i.m. in both deltoid muscles. HRIG was not administered. Upon his return to Zagreb, PEP was continued and finished at the $\mathrm{Za}-$ greb Antirabies Clinic with PCEC (Rabipur) rabies vaccine because PVRV was not available.

The main reason for not administering PVRV in the Zagreb Antirabies Clinic was that this vaccine was not officially registered for human PEP in the Republic of Croatia, contrary to the other two vaccines, on human diploid cells (HDC) and PCEC.

All monkey bites and injuries are listed in Table 1.
Table 1. Postexposure prophylaxis (PEP) according to geographical location of monkey bites and injuries registered in the Zagreb Antirabies Clinic in 2014

\begin{tabular}{|l|l|l|}
\hline $\begin{array}{l}\text { Geographic location } \\
\text { of the event }\end{array}$ & $\begin{array}{l}\text { Received } \\
\text { PEP } \\
\text { (yes/no) }\end{array}$ & $\begin{array}{l}\text { PEP } \\
\text { continued/finished } \\
\text { in Zagreb (yes/no) }\end{array}$ \\
\hline Zagreb City ZOO & No & No \\
Agra, India & Yes & Yes \\
India & Yes & Yes \\
Thailand & Yes & Yes \\
Thailand & Yes & Yes \\
Thailand & Yes & Yes \\
Bali & Yes & Yes \\
Bali & Yes & Yes \\
Bali & Yes & Yes \\
Indonesia & Yes & Yes \\
\hline
\end{tabular}

\section{Discussion}

Travelling to distant and exotic destinations always carries a certain risk for travelers due to many potential risks such as hygiene, food and water safety, infectious diseases, contact with insects or, sometimes, with animals. Monkey bites and injuries do not represent a routine threat at an antirabies clinic, but they do pose serious problems for travelers visiting exotic destinations such as Bali, Indonesia, India, or Thailand.

Monkeys are a large and varied group of mammals of the primate order. The term monkey includes all primates that do not belong to the categories of human, ape, or prosimian; however, monkeys do have certain common features. They all are excellent climbers, and most are primarily arboreal. Nearly all of them live in tropical or sub-tropical climates.

There are two large groups, or superfamilies of monkeys, i.e. Old World monkeys (Cercopithecoidea) and New World monkeys (Ceboidea).

The Old World monkeys inhabit South Asia, with a few species found as far north as Japan and north China, and Africa except for its deserts. The Old World monkeys include many species of macaques, widely distributed throughout Africa and Asia, among them rhesus monkey commonly used in laboratory experiments, as well as baboons in Africa and South West Asia, and mandrills and mangabeys in Africa.

The New World monkeys, found from south Mexico to central South America, except for high moun- 
tains, are classified into two families, Callatrichids and Cebids. The Callatrichids are very small, whereas the Cebids are similar in size to the Old World monkeys ${ }^{2}$.

Although Bali was thought to be a rabies-free destination, dog-mediated rabies has been present in Bali since $2008^{3}$, and many people died to date. Therefore, one of the recommendations for travelers to Bali is to receive a pre-exposure antirabies treatment $(\mathrm{PReP})$ of three doses of rabies vaccine on days $0,7,21$ or $28^{4}$.

The risk of receiving bite(s) or injuries from monkeys in wildlife is extremely rare, as travelers are not guided to deep forests or jungles. Instead, incidents usually occur when tourists visit monkey temples or forests ${ }^{5}$.

Several destinations in Southeast Asia, in particular Ubud and Pura Luhur Uluwatu in Bali; Angkor National Park in Siem Reap Cambodia; Krabi, Thailand, Batu Caves in Malaysia, are often reported to be 'a monkey problem'. They are usually home to a large population of macaque monkeys that live side-by-side with humans and are not afraid of them ${ }^{6}$.

Many travelers have been bitten by monkeys while trying to photograph, feed or pet monkeys when visiting the Ubud monkey forest in Bali ${ }^{7,8}$. As many as 14 people exposed to rabies were treated by Mackay region health services in 2016, mostly due to monkey bites and scratches 9 .

The risk of rabies exists not only in Bali but in entire Indonesia ${ }^{10}$. Recommendations have therefore been made for all travelers to receive PReP prior to their travel and to try to avoid any contact with animals, including monkeys, during their stay there. The main reason for such recommendations was difficulty with obtaining PEP, even in big cities.

In his report on rabies in India, Menezes has identified monkeys as an animal species of potential risk for travelers because of their susceptibility to rabies virus, and stressed the need of getting PEP after contact with monkeys ${ }^{11}$. Due to the great number of human deaths from rabies, the author suggests that PReP should be added to routine childhood immunization schedule.

Di Quinzio and McCarthy in a popular form of frequently asked questions have described the rabies risk among travelers and provided recommendations in case animal bite occurs during travel ${ }^{12}$. The most important of these are avoiding contact with animals, $\mathrm{PReP}$ in case of travelling to a rabies endemic country, immediate cleansing of the wound with soap and water, and seeking medical help to start PEP.

According to the official patient registry at the $\mathrm{Za}^{-}$ greb Antirabies Clinic, 11 monkey bites and injuries were registered between 2009 and 2013. In 2009, there were three registered monkey bites and injuries imported from Bali, Morocco and Cambodia; one was imported from Thailand in 2010, and one injury occurred in the Zagreb City ZOO in 2011. In 2012, there was one case imported from Thailand, and in 2013 there were two cases imported two from Thailand, one from Bali, and two were indigenous cases from the city of Zagreb (one in a pet monkey owner, and the other in a professional animal handler in the Zagreb City ZOO).

Almost all bites were inflicted due to visiting monkey temples, refusing to give food to monkeys, or trying to take a photo with monkeys. Ten patients had received antirabies vaccine in the countries of the incident, and finished their PEP at the Zagreb Antirabies Clinic. They all received PVRV and continued with PCEC (Rabipur) because PVRV was not officially registered for human PEP in the Republic of Croatia (only HDC and PCEC were registered at the time). One patient received HRIG after returning to Zagreb because he had been severely bitten to his legs during his honeymoon. PEP was continued with PCEC (Rabipur) vaccine, according to the 5-dose Essen scheme $^{13}$.

Monkeys as an animal species do not exist in the wildlife of the Republic of Croatia. The only possible way of being injured by them is at the Zagreb City $\mathrm{ZOO}$ or if they are kept as pets. Three monkey incidents were reported in the Zagreb City ZOO, and professional animal handlers were involved in all cases; only one incident occurred in the home of a pet monkey owner.

Unpleasant tourist experiences with monkeys in Cambodia have been reported on several web sites ${ }^{14,15}$. For this reason, recommendations and safety tips for travelers include guidelines on how to avoid monkey bites and attacks ${ }^{6,16}$. The most important one is that any bite or claw-scratch inflicted by monkeys requires immediate medical attention.

Monkey bites and injuries also occur in other parts of Asia, such as Katmandu, Nepal, with numerous Buddhist temples ${ }^{17}$. They are often densely populated with monkeys (rhesus), which play a role in Hindu and Bud- 
dhist culture ${ }^{18}$. One of these is Swoyambhu Temple. As macaques are a species most often associated with temples, people who live or work there come into contact with them more frequently than tourists ${ }^{19}$. Hence, monkey temples globally register the majority of the humanprimate contacts ${ }^{20}$.

Macaque body fluids have been reported to contain other infectious agents such as cercopithecine herpesvirus 1 (CHV-1); luckily, no cases of CHV-1 have been documented in persons exposed to free-ranging macaques $^{17}$. A case of human-to-human transmission of CHV-1 has, however, been documented ${ }^{21}$.

Infection with human SV 40 virus, a polyomavirus enzootic among rhesus macaque monkeys of Northern India and Nepal, has been reported among ZOO employees working with primates ${ }^{22}$.

Rhesus cytomegalovirus (RhCMV), cercopithecine herpesvirus 8, can cause illness and death in rhesus macaques co-infected with immunosuppressive retroviruses $^{23}$, or in experimentally infected rhesus macaque fetuses ${ }^{24}$, but no human infection with RhCMV has been reported ${ }^{25}$.

Macaques can harbor several enzootic retroviruses, including simian foamy virus (SFV), simian type D retrovirus (SRV), and simian T-cell lymphotropic virus $(\mathrm{STLV})^{20,26}$. ZOO workers and bushmeat hunters in Africa, as well as temple workers in Indonesia have been reported to be infected with SFV and SRV ${ }^{27}$.

A study on animal and human bites in children in Nigeria in a twelve-year period (1994-2005) has reported an official hospital record of monkey bite besides those inflicted by dog, humans and $\operatorname{rats}^{28}$. A retrospective analysis of suspected rabies cases reported at the Bugando Referral Hospital, Mwanza, Tanzania, has described a bite of a vervet monkey (Cercopithecur aethiops) besides those by dogs, cats, spotted hyena and blackbacked jackal ${ }^{29}$.

Rasania et al..$^{30}$ in their article about postexposure management of animal bite cases attending a primary health center of Delhi report on 147 cases of animal bites, and monkey was the second animal afflicting wounds and injuries, immediately after dog. Chhabra et $a l .{ }^{31}$ in their article about human rabies in Delhi analyzed human rabies cases admitted to the Infectious Disease Hospital, Delhi. The biting animals involved were predominantly dog with $96.7 \%$, followed by jackal $(1.7 \%)$, cat $(0.8 \%)$, monkey $(0.4 \%)$ and mongoose $(0.4 \%)$. The majority of patients had category III expo- sure. Most of them did not receive any local wound treatment and had never received any vaccination, while the remaining patients were inadequately vaccinated. Only five of them received 10-14 injections of neural tissue vaccine (NTV). The main conclusion is that rabies can be successfully prevented but education of the community and health care professionals is of great importance.

Shetty et al..$^{32}$ report on a cross-sectional study that was carried out to determine the profile of animal bite cases reporting to the Anti Rabies Clinic at the Sassoon Hospital, Rune. Out of 250 cases recorded in the study, the biting animals involved were $\operatorname{dog}(94.4 \%)$, cat (2.4\%), jackal (1.2\%), mongoose (1.2\%), monkey (0.4\%) and horse $(0.4 \%)$. Children of the $0-14$ age group were victims in 132 cases.

Ichpujani et al. ${ }^{33}$ in their article on the epidemiology of animal bites and rabies cases in India (a multicenter study) report on monkey as the second most common biting animal (3.2\%), following dog with maximum morbidity (92\%). Almost $50 \%$ of cases were children of the $2-18$ age group. The authors conclude that there is the need to upgrade awareness regarding epidemiology and at-home and hospital management of animal bites among service providers and general community.

Monkey bites are frequently reported among children travelling to distant and exotic countries and can be associated with transmission of zoonoses. Besides rabies and other bacterial and viral diseases, there is the risk of potential fatal transmission of herpes $B$ virus infection from macaque bites. Although the risk for travelers is still unknown, such cases have been well documented in medical facilities ${ }^{17,21,22}$. Ritz et al. ${ }^{34}$ have described a case of a 7-year-old girl who was bitten by a monkey while visiting a sanctuary in Koh Samui, Thailand, where monkeys can be touched, carried and fed by tourists. The bite occurred when the girl picked up a banana from the ground to feed one of the monkeys. The monkey jumped on the girl's arm, grabbed her hair, and bit her into her forehead. This resulted in an open wound at the site of the bite with subsequent scab formation. She received PEP with antirabies vaccine on human diploid cells i. m. according to the 4-dose schedule on days $0,3,7$ and 14 , and HRIG. She also received postexposure prophylaxis for herpes B virus with valacyclovir at $20 \mathrm{mg} / \mathrm{kg}$ per dose 3 times per day for 14 days, but after 2 weeks this therapy was discontinued. The monkey species later on identified by the girl on 
photos provided by the family were pigtail macaque (Macaca nemestrina) and rhesus macaque (Macaca mulata). The authors conclude that there are currently no guidelines for the management of possible herpes B exposure after monkey bites in travelers; however, most important of all is the fact that all travelers should be warned about the hazards associated with monkeys and importance of wound cleansing immediately after exposure. Tregle et al..$^{35}$ have described a case of a child bitten by a Bonnet Macaque monkey and the risk of transmission of cercopithecine herpesvirus 1. After consultation with animal authorities, the child received proper treatment, which included wound care, rabies prophylaxis, irrigation with sodium hypochlorite solution, and treatment with antiviral medication.

French authors Bréhin et al. ${ }^{36}$ have described two cases of macaque bites in two pediatric cases (a 4-yearold boy and 10-year-old girl). The first one happened in a North African ZOO in Tunis, Africa, and the other one in Indonesia on Bali Island. In this article, the authors give recommendations what to do after being bitten by a monkey. These include appropriate wound treatment which has to be started immediately; the site of the wound should be cleansed for 15 minutes using a solution containing a detergent soap (e.g., chlorhexidine, povidone iodine); or normal saline in the case of ocular involvement. Postexposure prophylaxis for bacterial, rabies and herpesvirus infections must be initiated, preferably in the first 5 days. Blood samples and wound swabs should be sent as soon as possible to a reference laboratory for herpesvirus serology and specific polymerase chain reaction (PCR) assays. Follow up visits should be scheduled at 6 weeks postexposure, along with follow up serology and PCR assays. Almost identical recommendations can be found in monkey bite/exposure protocols in Iowa (especially regarding macaque monkeys) ${ }^{37}$.

Johnston et al..$^{38}$ present a case of a 26-year-old female who was bitten by a wild macaque monkey while being on a trip to Bali. Except for PEP with antirabies vaccine and human rabies immunoglobulin, she also received acyclovir for prophylaxis against herpes B virus, which is a deadly zoonotic agent that is endemic among macaque monkeys. The authors also discuss the necessity of antiviral prophylaxis based on recommendations of the Centers for Disease Control and Prevention ${ }^{39}$.

Mills et al. ${ }^{5}$ in their article discuss animal bites and rabies exposure in Australian travelers. This mostly hap- pened in travelers aged 20-29 years. Most injuries occurred in Bali, Indonesia and Thailand, and the most common animals responsible for injuries to 65 travelers were monkeys and dogs. They also discuss the pre-exposure rabies vaccination and postexposure prophylaxis. Only one traveler had received pre-exposure rabies vaccination. Forty travelers commenced PEP while overseas, and only nine of these were able to receive rabies immunoglobulin (RIG). Some travelers received RIG after they returned to Australia, and those who presented more than 7 days from their first rabies vaccine did not receive RIG. Only 35 travelers completed PEP as recommended by the World Health Organization (WHO) and received RIG and all doses of the vaccine. The authors conclude that all travelers who are travelling to rabies endemic countries should be well informed about the risk of animal bites and getting preexposure rabies vaccination and postexposure prophylaxis in case of exposure.

Riesland and Wilde ${ }^{40}$ in their article discuss the potential threats to travelers suffering injuries inflicted by non-human primates, and that clinicians should inform them about the potential threats and discuss published recommendations with their patients prior to arriving to treatment plan. They are discussing rabies, herpes $\mathrm{B}$ virus, and other possible threats that monkeys can transfer to humans. The main conclusion is that travelers should receive detailed counseling prior to their departure to distant destinations, and check whether appropriate medical facilities are in their proximity and are available to perform and follow current medical published recommendations.

Besides travelers, monkey bites were recorded among professional soldiers. Mease and Baker ${ }^{41}$ in their article discuss monkey bites among US military members in Afghanistan in 2011. Out of 126 animal bites and exposures, 10 were monkey bites. All cases involved different monkeys, 8 of which were kept as pets. Of these 8 pet monkeys, 4 belonged to Afghan $\mathrm{Na}$ tional Security Forces, 3 to Afghan civilians, and 1 to US military members. For 2 monkeys, ownership data were not available.

All these cases were evaluated and treated according to current medical recommendations which include wound care, antiviral medications for herpes Bvirus, antimicrobial drugs for oral bacteria, verification of up-to-date tetanus vaccination status or vaccine administration in accordance with Advisory Commit- 
tee on Immunization Practices (ACIP) guidelines ${ }^{39}$, and rabies PEP. US military policy advised that rabies PEP should be given either according to the WHO official guidelines ${ }^{42}$, which include administration of HRIG with 5 doses of rabies vaccine, or according to ACIP recommendations with HRIG plus 4 doses of rabies vaccine ${ }^{43}$. The conclusion emphasizes caution with monkeys, education of military health care providers, and to follow current medical published recommendations in case of bite/injury.

In their article, Leung et al. ${ }^{44}$ describe a Zika virus infection in Australia following a monkey bite in Indonesia. A 27-year-old patient was bitten by a macaque monkey in Ubud Monkey Forest in Bali, and after returning to Australia he developed Zika virus infection with fever, rash and conjunctivitis, with onset five days after the monkey bite. Flavivirus RNA detected on PCR from a nasopharyngeal swab was sequenced and identified as Zika virus.

Although Zika virus infection is usually transmitted to humans by mosquitoes, the authors suggest that macaque monkey bite should be considered as a plausible route of $\mathrm{Zika}$ virus transmission.

The WHO discusses monkey bites on their official web site about animal bites ${ }^{45}$. Monkey bites account for $2 \%-21 \%$ of animal bite injuries, and in India two studies $^{30,33}$ found monkeys to be second to dogs as the most common source of animal bite injuries. No matter what kind of exposure happened to travelers, in almost every country, medical staff should follow the official WHO guide for postexposure prophylaxis. Every country is free to choose which of the WHO recommended schedules will use for postexposure prophylaxis in humans ${ }^{46}$.

Besides WHO, the authors writing about animalassociated hazards in the newly published CDC Health Information for International Travel 2018: The Yellow Book, strongly advise travelers to follow current medical recommendations in case of monkey bites/injuries with wound care treatment and rabies and herpes B prophylaxis ${ }^{47}$.

The best possible way to avoid any contact or injury by monkeys is to stay home and watch them on TV in your living room. However, in case that people decide to travel to a distant and exotic destination, they should check all relevant data and follow official recommendations. In case of any bite or claw-scratch injury after contact with monkeys, it is essential to cleanse the wounds with soap and water for 15 minutes and seek for medical assistance in the nearest medical facility.

\section{References}

1. World Health Organization [Internet]. Geneva: WHO; c2017 [cited 2017 Jul 2]. International Travel and Health: General precautions. Available from: http://www.who.int/ith/precautions/en/

2. World Animal Foundation [Internet]. Oneida, Kentucky: WAF; c2017 [cited 2017 Jul 2]. Monkey Fact Sheet. Available from: http://www.worldanimalfoundation.net/f/monkey.pdf

3. BIMC Hospital [Internet]. Bali, Indonesia: BIMC Hospital Kuta; c2017 [cited 2017 Jul 2]. Rabies Then and Now. Available from: http://bimcbali.com/health-e-update/rabies-now.html

4. BIMC Hospital [Internet]. Bali, Indonesia: BIMC Hospital Kuta; c2017 [cited 2017 Jul 2]. Pre-Travel Vaccination for Adult Travelers to Bali. Available from: http://bimcbali.com/ health-e-update/health-tips/pre-travel-vaccination.html

5. Mills DJ, Lau CL, Weinstein P. Animal bites and rabies exposure in Australian travellers. Med J Aust. 2011;195:673-5. doi: 10.5694/mja10.11413

6. Rodgers G. Southeast Asia's Monkeys: Handle with Care: How to Avoid Monkey Bites and Attacks. [Internet]. 2017 May 16. [cited 2017 Jul 2]. Available from: http://goseasia. about.com/od/travelplanning/a/avoiding_monkey_attacks.htm

7. Cronshaw D. NSW man faces rabies risk after monkey bites in Bali. [Internet]. 2016 March 15 [cited 2017 Jul 2]. In: The Sydney Morning Herald. Sydney: SMH; c2017. Available from: http://www.smh.com.au/nsw/nsw-man-faces-rabies-risk-after -monkey-bites-in-bali-20160315-gnjbpd.html

8. Lusher J. The Sacred Monkey Forest Sanctuary - Ubud, Bali Indonesia [Internet]. 2016 Nov 14 [cited 2017 Jul 2]. Available from: http://jameslusherphotography.squarespace.com/blog/ 2016/11/12/the-sacred-monkey-forest-sanctuary-ubud-bali

9. Mortimer L. Bali monkey bites: travellers exposed to rabies treated in Mackay. [Internet]. 2016 Nov 1 [cited 2017 Jul 2]. In: Daily Mercury. Mackay, Queensland: The Mackay Printing and Publishing Company Pty Ltd; c2017. Available from: https://www.dailymercury.com.au/news/bali-monkey-bitestravellers-exposed-to-rabies-tre/3106832/

10. Living in Indonesia: a Site for Expatriates. Rabies in Indonesia. [Internet]. Jakarta, Indonesia: Expat Web Site Association Jakarta, Indonesia; c1997-2017 [cited 2017 Jul 2]. Available from: http://www.expat.or.id/medical/rabies.html

11. Menezes R. Rabies in India. CMAJ. 2008;178:564-6. doi: 10.1503/cmaj.071488

12. Di Quinzio M, McCarthy A. Rabies risk among travellers. CMAJ. 2008;178:567. doi: 10.1503/cmaj.071443

13. Archives of the Zagreb Antirabies Clinic - Official Patient Registry, 2014.

14. The Gap Year Travel Guide. I was bitten by a monkey in Cambodia. [Internet]. Birmingham: British American Group; 
c2006-2017 [cited 2017 Jul 2]. Available from: http://www. gapyear.travel/survival_kit/article/i_was_bitten_by_a_monkey _in_cambodia

15. Southeast Asia Eco. Beware the monkeys of Angkor Wat! [Internet]. Toronto: Operation Groundswell; c2017 [cited 2017 Jul 2]. Available from: http://operationgroundswell.com/sea/ beware-monkeys-at-angkor-wat/

16. How to Prevent or Survive a Monkey Attack [Internet]. Palo Alto, CA: WikiHow; c2017 [cited 2017 Jul 2]. Available from: http://www.wikihow.com/Prevent-or-Survive-a-Monkey-Attack\#Taking_Proper_Precautions_sub

17. Jones-Engel L, Engel GA, Heidrich J, Chalise M, Poudel N, Viscidi R, Barry PA, Allan JS, Grant R, Kyes R. Temple monkeys and health implications of commensalism, Kathmandu, Nepal. Emerg Infect Dis. 2006;12:900-6. doi: 10.3201/eid 126.060030

18. Fuentes A, Gamerl S. Disproportionate participation by age/ sex classes in aggressive interactions between long-tailed macaques (Macaca fascicularis) and human tourists at Padangtegal monkey forest, Bali, Indonesia. Am J Primatol. 2005;66: 197-204. doi: 10.1002/ajp.20138

19. Engel GA, Jones-Engel L, Schillaci MA, Suaryana KG, Putra A, Fuentes A, Henkel R. Human exposure to herpesvirus Bseropositive macaques, Bali, Indonesia. Emerg Infect Dis. 2002;8:789-95. doi: 10.3201/eid0805.010467

20. Jones-Engel L, Engel GA, Schillaci MA, Rompis A, Putra A, Suaryana KG, Fuentes A, Beer B, Hicks S, White R, Wilson B, Allan JS. Primate-to-human retroviral transmission in Asia. Emerg Infect Dis. 2005;11:1028-35. doi: 10.3201/eid1107. 040957

21. Centers for Disease Control and Prevention. B-virus infection in humans - Pensacola, Florida. MMWR Morb Mortal Wkly Rep. 1987;36:289-90, 295-6. PubMed PMID: 3033462

22. Engels EA, Switzer WM, Heneine W, Viscidi RP. Serologic evidence for exposure to simian virus 40 in North American zoo workers. J Infect Dis. 2004;190:2065-9. doi: 10.1086/425997

23. Kaur A, Kassis N, Hale CL, Simon M, Elliott M, Gomez-Yafal A, Lifson JD, Desrosiers RC, Wang F, Barry P, Mach M, Johnson RP. Direct relationship between suppression of virus-specific immunity and emergence of cytomegalovirus disease in simian AIDS. J Virol. 2003;77:5749-58. doi: 10.1128/JVI. 77.10.5749-5758.2003

24. Chang WL, Tarantal AF, Zhou SS, Borowsky AD, Barry PA. A recombinant rhesus cytomegalovirus expressing enhanced green fluorescent protein retains the wild-type phenotype and pathogenicity in fetal macaques. J Virol. 2002;76:9493-504. doi: 10.1128/JVI.76.18.9493-9504.2002

25. Alcendor DJ, Barry PA, Pratt-Lowe E, Luciw PA. Analysis of the rhesus cytomegalovirus immediate-early gene promoter. Virology. 1993;194:815-21. doi: 10.1006/viro.1993.1323

26. Switzer WM, Bhullar V, Shanmugam V, Cong ME, Parekh B, Lerche NW, Yee JL, Ely JJ, Boneva R, Chapman LE, Folks TM, Heneine W. Frequent simian foamy virus infection in per- sons occupationally exposed to nonhuman primates. J Virol. 2004;78:2780-9. doi: 10.1128/JVI.78.6.2780-2789.2004

27. Wolfe ND, Switzer WM, Carr JK, Bhullar VB, Shanmugam V, Tamoufe U, Prosser AT, Torimiro JN, Wright A, MpoudiNgole E, McCutchan FE, Birx DL, Folks TM, Burke DS, Heneine W. Naturally acquired simian retrovirus infections in Central African hunters. Lancet. 2004;363:932-7. doi: 10.1016/s0140-6736(04)15787-5

28. Osaghae DO. Animal and human bites in children. West Afr J Med. 2011;30:421-4. PubMed PMID: 22786858.

29. Mazigo HD, Okumu FO, Kweka EJ, Mnyone LL. Retrospective analysis of suspected rabies cases reported at Bugando Referral Hospital, Mwanza, Tanzania. J Glob Infect Dis. 2010; 2:216-20. doi: 10.4103/0974-777x.68530

30. Rasania SK, Bhalla S, Khandekar J, Pathi S, Matta S, Singh S. Post exposure management of animal bite cases attending a primary health center of Delhi.J Commun Dis. 2004;36:195-8. PubMed PMID: 16509257.

31. Chhabra M, Ichhpujani RL, Tewari KN, Lal S. Human rabies in Delhi. Indian J Pediatr. 2004;71:217-20. PubMed PMID: 15080408 .

32. Shetty RA, Chaturvedi S, Singh Z. Profile of animal bite cases in Pune. J Commun Dis. 2005;37:66-72. PubMed PMID: 16637403.

33. Ichhpujani RL, Mala C, Veena M, Singh J, Bhardwaj M, Bhattacharya D, Pattanaik SK, Balakrishnan N, Reddy AK, Samnpath G, Gandhi N, Nagar SS, Shiv L. Epidemiology of animal bites and rabies cases in India. A multicentric study. J Commun Dis. 2008;40:27-36. PubMed PMID: 19127666.

34. Ritz N, Curtis N, Buttery J, Babl FE. Monkey bites in travelers: should we think of herpes B virus? Pediatr Emerg Care. 2009;25:529-31. doi: 10.1097/PEC.0b013e3181b0a45c

35. Tregle RW Jr, Loe CL, Earhart RH $3^{\text {rd }}$, d'Autremont SB. Cercopithecine herpesvirus 1 risk in a child bitten by a Bonnet macaque monkey. J Emerg Med. 2011;41:e89-90. doi: 10.1016/j.jemermed.2010.02.011

36. Brehin C, Debuisson C, Mansuy JM, Niphuis H, Buitendijk H, Mengelle C, Grouteau E, Claudet I. Keep children away from macaque monkeys! J Travel Med. 2016;23. doi: 10.1093/ $\mathrm{jtm} / \mathrm{taw} 006$

37. Iowa Department of Public Health. Monkey bite/exposure protocols. [Internet]. Iowa: Iowa Department of Public Health; c2017 [cited 2017 Jul 2]. Available from: https://idph.iowa. gov/Portals/1/userfiles/79/Documents/Monkey\%20Bite\%20 Protocol.pdf Accessed 2017, June 24

38. Johnston WF, Yeh J, Nierenberg R, Procopio G. Exposure to macaque monkey bite. J Emerg Med. 2015;49:634-7. doi: 10.1016/j.jemermed.2015.06.012

39. Centers for Disease Control and Prevention. Updated recommendations for use of tetanus toxoid, reduced diphtheria toxoid and acellular pertussis (Tdap) vaccine from the Advisory Committee on Immunization Practices, 2010. MMWR Morb Mortal Wkly Rep. 2011;60:13-5. PubMed PMID: 21228763. 
40. Riesland NJ, Wilde H. Expert review of evidence bases for managing monkey bites in travelers. J Travel Med. 2015;22: 259-62. doi: 10.1111/jtm.12214

41. Mease LE, Baker KA. Monkey bites among US military members, Afghanistan, 2011. Emerg Infect Dis. 2012;18:1647-9. doi: 10.3201/eid1810.120419

42. World Health Organization. Rabies vaccines: WHO position paper - recommendations. Vaccine. 2010;28:7140-2. doi: 10.1016/j.vaccine.2010.08.082

43. Centers for Disease Control and Prevention. Use of a reduced (4-dose) vaccine schedule for postexposure prophylaxis to prevent human rabies - recommendations of the Advisory Committee on Immunization Practice. Ann Emerg Med. 2010; 56:64-7. doi: 10.1016/j.annemergmed.2010.05.020

44. Leung GHY, Baird RW, Druce J, Anstey NM. Zika virus infection in Australia following a monkey bite in Indonesia.
Southeast Asian J Trop Med Public Health. 2015;46:460-4. PubMed PMID: 26521519.

45. World Health Organization [Internet]. Geneva: WHO; c2017 [cited 2017 Jul 2]. Animal bites: fact sheets. Available from: http://www.who.int/mediacentre/factsheets/fs373/en/

46. World Health Organization [Internet]. Geneva: WHO; c2017 [cited 2017 Jul 2]. WHO guide for pre- and postexposure prophylaxis in humans. Available from: http://www.who.int/rabies /PEP_Prophylaxis_guideline_15_12_2014.pdf

47. Bair-Brake H, Wallace RM, Galland GG, Marano N. Animalassociated hazards. In: CDC Yellow Book 2018: Health Information for International Travel. [Internet]. Atlanta: Centers for Disease Control and Prevention; c2017 [cited 2017 Jul 2]. Available from: https://global.oup.com/academic/product/cdc -yellow-book-2018-health-information-for-international-travel-9780190628611?q=CDC\%20Health\%20Information $\% 20$ for\%20International\%20Travel\%202017\&lang=en\&cc=us\#

Sažetak

\title{
UGRIZI I OZLJEDE OD MAJMUNA U ANTIRABIČNOJ AMBULANTI GRADA ZAGREBA U 2014. GODINI
}

\author{
R. Vodopija, D. Vojvodic, K. Sokol, A. Racz, Ž. Gregurić Beljak, N. Baranj, J. Mahović i B. Ulaga
}

Putovanje diljem svijeta i posjet udaljenim mjestima i zemljama (osobito nacionalnim parkovima, parkovima prirode, prirodnim rezervatima i slično) ponekad može rezultirati ugrizom i ozljedom životinjskih vrsta koje su rijetko izvor humanih slučajeva bjesnoće, kao što su majmuni. U posljednjih 10 do 15 godina ugrizi i ozljede nanesene od majmuna predstavljaju neugodno iskustvo i uzrokuju podosta problema, naročito putnicima koji putuju u Indiju, Tajland, Indoneziju ili Bali, budući da se zbog istih trebaju javiti u medicinsku ustanovu radi obrade rane, antitetanusne profilakse, antibiotske terapije i nerijetko postekspozicijske antirabične profilakse (PEP). U Antirabičnoj ambulanti Referentnog centra za bjesnoću pri Nastavnom zavodu za javno zdravstvo "Dr. Andrija Štampar" u 2014. godini zbog ugriza životinja pregledano je ukupno 706 osoba koje su ugrizle različite vrste životinja, među kojima je bilo registrirano 10 ozljeda zadanih od majmuna. Devetoro osoba zadobilo je ozljede od majmuna prilikom putovanja u Indiju, Tajland, Indoneziju i Bali. Sve ozljede dogodile su se dok su osobe željele gladiti i maziti majmune, pokušale ih hraniti ili im odbile dati hranu. U većini slučajeva radilo se o majmunima vrste makaki, kapucini ili nepoznate vrste majmuna. U jedinom slučaju ozljede od majmuna na području grada Zagreba radilo se o profesionalnom djelatniku Zagrebačkog zoološkog vrta koji je u kavezu hranio majmuna vrste kapucin. On, za razliku od ostalih pacijenata, nije primio postekspozicijsku antirabičnu profilaksu (PEP), nego je majmun stavljen pod veterinarski nadzor. Ostalih devetoro osoba započelo je PEP u zemljama gdje su se dogodile ozljede, a PEP su završile u Antirabičnoj ambulanti grada Zagreba. Pacijenti su primili PEP samo primjenom antirabičnog cjepiva na vero stanicama (PVRV) ili na supstratu pilećih fibroblasta (RABIPUR) prema 5-doznoj shemi (Essenska shema) i 2-1-1 shemi cijepljenja protiv bjesnoće (Zagrebačka shema). Nitko od tretiranih pacijenata nije razvio znakove bjesnoće. Nakon mnogo godina majmuni su životinjska vrsta koja se uz pse i mačke pojavila u službenom izvješću Antirabične ambulante grada Zagreba te zbog toga predstavljaju veliko iznenađenje. Obično ugrizi i ozljede od majmuna ne predstavljaju ozbiljan problem u svakodnevnom radu, jer se javljaju sporadično.

Ključne riječi: Putovanje; Haplorbini; Bjesnoća; Ugrizi i ozljede; Hrvatska 